\title{
The challenges faced by halal certification authorities in managing the halal certification process in Malaysia
}

\author{
${ }^{1}$ Muhammad, M.A., ${ }^{1,2, *}$ Elistina, A.B. and ${ }^{1,2}$ Ahmad, S. \\ ${ }^{1}$ Halal Products Research Institute, Universiti Putra Malaysia, 43400 UPM Serdang, Selangor, Malaysia \\ ${ }^{2}$ Faculty of Human Ecology, Universiti Putra Malaysia, 43400 UPM Serdang, Selangor, Malaysia
}

Article history:

Received: 22 August 2019

Received in revised form: 24

December 2019

Accepted: 30 December 2019

Available Online: 10

February 2020

Keywords:

Halal certification,

Halal authority,

Challenges

DOI:

https://doi.org/10.26656/fr.2017.4(S1).S17

\begin{abstract}
The massive demand for halal food is the main reason business enterprises engage in halal food production, namely for the purpose of increasing profits. Halal certification has been managed by Malaysian halal certification authorities, namely the Islamic Development Department Malaysia (JAKIM) and the State Islamic Religious Department (JAIN). This study triangulates the viewpoints of Halal Auditors, Halal Executives, and Halal Certification Panel in managing the halal certification process in Malaysia. The main aim of this study is to explore the challenges faced by halal certification authorities and the initiatives that can be taken to improve their roles. A qualitative research method via indepth interviews with Halal Auditors from JAKIM and JAIS, Halal Certification Panel, and Halal Executives from various companies has been used to gather the data for this study. Findings from the interviews highlighted six challenges in the halal certification process which are lack of manpower, Halal Auditor's lack of skills and knowledge, problems with MYeHALAL system, issues in reviewing halal certification applications, lack of proper guidelines in Malaysia halal certification, and competition from the foreign certification body. The initiatives and suggestions to improve the standard and performance of the Malaysian halal certification authorities are also highlighted. In terms of practical implications, the findings of this study can be used as baseline data for any policy intervention and improvement or advocacy efforts related to halal certification process in Malaysia.
\end{abstract}

\section{Introduction}

Over the last few years, the issue of the halal status of products has appeared on the agenda of educators, consumer groups, businesses, government agencies, policymakers, and even grass-root consumers. Recognizing the importance of 'halal' status to consumers, traders have used the concept of halal as a form of marketing (Wilson and Liu, 2010). Halal logos, Arabic language, and Jawi writing have been used on food labels to influence consumers to buy the products. A study by Osman et al. (2019) highlighted that any practice which exploits Islam in business activity (either exploiting the Al-Quran or As-Sunnah) is prohibited as this may lead to defamation against Islam, harm one's health, and even deviate the faith of a Muslim. Therefore, these activities need to be curbed and regulated in order to protect the sanctity of Islam. The Malaysian government has put in good effort by enacting the Trade Description Act 2011 and two relevant subsidiary legislations, namely the Trade Description (Certification and Marking of Halal) Order 2011 and the
Trade Description (Definition of Halal) Order 2011. By virtue of these laws, the meaning of the halal concept is properly defined and more clearly understood. This will benefit both suppliers as well as consumers. Additionally, only the halal logo from JAKIM and JAIS can be legally applied to any product and service premises. In order to obtain halal certification for products to be marketed locally as well as exported internationally, the application can be made to either JAKIM or JAIS. Meanwhile, for products manufactured outside Malaysia, if the manufacturers are keen to market them here, they are permitted to use the halal certification and $\log 0$ by foreign halal certification bodies recognized by JAKIM (Buang and Mahmod, 2012; Zakaria and Ismail, 2014). JAKIM had given recognition to 16 halal authorities and 72 Islamic bodies from 33 countries that have similar guidelines with the Malaysia Halal Certificate guidelines (Wahab et al., 2016). Although the Trade Description Act 2011 and its Orders have strengthened the position of the halal concept and benefited both suppliers and consumers, 
they function mainly to give more authority to the enforcement bodies to regulate trade activities. They are used as a means of deterring suppliers from engaging in trading abuses related to the halal logo in Malaysia.

Pursuant to Clause 2 of the Trade Descriptions (Certification and Marking of Halal) Order 2011, the Manual Procedure for Malaysia Halal Certification 2014 (Jabatan Kemajuan Islam Malaysia (JAKIM), 2015) was issued. According to the MPFMHC 2014, there are three groups of professionals involved in the process of acquiring halal certification. They are the Halal Auditors, the Halal Executives, and the Halal Certification Panel. The Halal Auditors carry out the halal audit and they must have suitable qualifications with either Islamic or food technology background. In order to obtain the Malaysia Halal Certificate, a few steps need to be followed. Firstly, the Halal Auditor will receive an application from a Halal Executive of the applicant company. Among the tasks of the Halal Auditor are to review the documents, ensure fee payment, conduct compliance audit at the premise, prepare the report, and submit the results to the Halal Certification Panel during their meeting for approval. Meanwhile, the Halal Executive is the person in charge and responsible for managing the halal certification application put in by the company/industry. The criteria for a Halal Executive position are that they must be Malaysian Muslim citizens and they must either have a background in Islamic studies or they must have undergone halal executive training. The Halal Auditor will conduct an on-site audit and then make the necessary report. Any nonconformance must be recorded and detailed out in a Non -Conformance Report and corrective action must then be taken by the Halal Executive. Once the corrective action is completed and all requirements are fulfilled, the Halal Executive will resubmit the completed halal certification application to the Halal Auditor. The final stage of the halal certification process is to forward the application to the Malaysia Halal Certification Panel (HCP) for approval.

According to the MPFMHC 2014, the HCP is comprised of experts which include the Chairman, the Secretary, and two experts in shariah and technical committee. The appointment to sit on the HCP is for two years and can be renewed. Upon being appointed, the panel members must sign a Confidentiality Undertaking Letter and they must not be directly involved in the process of auditing and reviewing halal certification applications. The HCP is only responsible for making the final decision regarding halal certification applications. The decision can be pass, pass with conditions, keep-inview (KIV), fail, re-audit, or cancellation. For a surveillance audit case, the HCP can return or suspend the application. A surveillance audit is where an auditor is sent to check and verify that the organization's management system is in place along with all other necessary components. The decision made by the HCP is final and shall be recorded and kept for future reference. The applicants will then be notified of the status of their application (MPFMHC, 2014).

In February 2006, the e-halal system was launched to enable halal certification applications to be done online. The purpose of this system is to enhance productivity in the halal certification process, to give priority to halal certification applications from the industry, and to also serve as a database of companies, businesses, restaurants, hotels, and products. In April 2014, the e-halal system was rebranded as MYeHALAL, which segregates the halal application into seven different categories: (i) Food and Beverages Products; (ii) Consumable Products; (iii) Food Premises; (iv) Cosmetics and Toiletries; (v) Pharmaceuticals; (vi) Logistics; and (vii) Slaughterhouse (under the monitoring and supervision of JAKIM for domestic as well as international products). Therefore, all halal certification applications are to be done through JAKIM's MYeHALAL system. It is an online application which can be accessed through JAKIM's website. As MYeHALAL is concerned with information technology, it needs to be handled by staff that have at least basic Information Technology (IT) knowledge. By following the standard operational procedure (SOP), applications can be submitted after all the requirements have been fulfilled (Ibrahim et al., 2013; MPFMHC, 2014).

For many years, people have discussed halal issues especially relating to halal certification. Even though Malaysia has formulated guidelines, standards, and laws regulating the issue of halal status, Muslim consumers still face problems in ensuring that the products they buy are genuinely halal, as they can only rely on the certification given by the authorities (Khairi et al., 2012; Shahwahid et al., 2017). In 2014, there was an incident involving the deoxyribonucleic acid (DNA) of pork (porcine), alleged to have been discovered in two Cadbury products. Even though the allegation turned out to be false, this incident created strong negative reactions from Muslim consumers and this demonstrates the public's concerns regarding the issue of halal status in Malaysia. This issue has placed consumers, especially Muslims, in a state of worry and lacking confidence in the halal status of products in the market. The worst part is the potential lack of trust by consumers in Malaysia towards the halal certification authorities, especially JAKIM (Elistina et al., 2017).

A study carried out by Prabowo et al. (2015) showed 
that there are both internal and external factors affecting the halal certification process. Internal factors can be explained as the factors which emerge from the employers or employees within the organization itself, while external factors are factors that come from outside the organization. These challenges influence the implementation of a halal food management system, which is an element in the Halal Assurance System (HAS). HAS is the guidelines for the industries which promote the adoption of the system when implementing, developing, and improving the effectiveness of controlling halal purity. The system includes effective product recall procedures, effective documentation to enable traceability and proper filing system for halal applications.

Based on the findings by Ahmad et al. (2017), factors that affect the success of the halal certification system are, among others, lack of manpower and incompetent staff. Another factor is the lack of information about halal procedures in the mass media (Wan Hassan and Awang, 2009; Prabowo et al., 2015). According to Karaman, Cobanoglu, Tunalioglu and Ova (2012), halal certification manuals are quite complicated and cannot be easily understood. This leads to the nonMuslim entrepreneurs experiencing difficulty in understanding the halal certification process which is compounded with the halal and toyyiban concept. Soraji et al. (2017) listed out their concerns regarding the challenges faced by the government in developing the halal industry in Malaysia. Among others, there is a challenge to explain the correct concept of halal to both Muslim and non-Muslim companies. Employers/ companies sometimes wrongly assume that hiring Muslim staff and making them visible in the shop already fulfills the requirement or element of halal (Soraji et al., 2017).

A study by Buang and Mahmud (2012) pointed out that a Halal Act has still not been enacted and that prosecution under the law still depends on enforcement by other agencies. The National Halal Council Act is expected to be tabled soon. This piece of legislation is important to ensure that the function of each relevant agency is clear, which will strengthen the implementation of halal certification in Malaysia. Prabowo et al. (2015) mentioned that the halal certification process will be stalled when raw material used, especially meat-based products, do not have the halal logo. This matter makes it problematic for new applicants to apply for halal certification, causing them to refuse to apply for a halal certificate due to limited suppliers or abattoirs. Noordin et al. (2014) affirm these facts in their interviews with the industry players.
Another problem highlighted is that the halal application process takes too long. This is due to the strict SOP, delay in convening meetings by the HCP, and inflexible decisions made by the shariah officers. Marzuki et al. (2012) interviewed a few restaurant managers who had experience undergoing the process of applying for halal certification. The findings show that they have to wait for the halal certificate for six months, there are a lot of steps involved, and high costs have to be incurred. These are among the reasons why people refuse to apply for a halal certificate. The interviewees nevertheless agreed that applying for halal certification has educated them on the importance of maintaining cleanliness in their premises and in food preparation.

As an alternative, a third party can be hired to handle the halal certification process and address related issues. This was the function performed by the Halal Industry Development Corporation Sdn Bhd, an agency under the Ministry of International Trade and Industry. However, this alternative was not preferred and not supported by JAKIM because it leaves the process vulnerable to scams and leads to unnecessary costs being incurred (Arif et al., 2017). In order to overcome the existing problems, Noordin et al. (2014) asserted that there is a need to increase the knowledge and skills of officers, utilize a more updated technology system, improve customer service, and develop a checklist for halal raw materials. According to Arif et al. (2017), improvements in the MYeHALAL system will increase the number of applications for halal certification, which will, in turn, increase the number of halal-certified companies and strengthen the halal industry in Malaysia.

Meanwhile, Noordin et al. (2014) showed that the manufacturers contribute to the success of the halal certification process particularly in providing relevant information. First, in terms of company information, the Halal Auditor need the company profile, premise/factory map location, and company registration details. In terms of the product information, the Halal Auditor needs the products' names and information for verification purposes and a list of ingredients that have halal certification, especially the critical ingredients. The third element is the identification and appointment letters for the Halal Executives and Muslim staff working in the production section. A license from the Ministry of Health and a permit from the Department of Veterinary Services are two requirements that need to be fulfilled. Other quality certifications can also be useful in halal certification applications, such as Good Manufacturing Practice (GMP), Total Quality Management (TQM), Hazard Analysis Critical Control Point (HACCP), International Standard Organization (ISO) and Good Hygiene Practice (GHP) (Buang and Mahmod, 2012). 
From the executives' perspective, many feel that the requirements to be fulfilled for the halal certification application are tedious and burdensome. To get a fair and accurate picture, feedback from the certification authorities regarding the halal certification process should also be sought. In terms of knowledge and communication of the information needed for halal certification, there is a lack of synchronization (Hashim, and Shariff, 2016). There is no central point provided to make inquiries or obtain information. The Halal Executives have claimed that it is very difficult to obtain replies or answers to their queries from Halal Auditors regarding their halal certification applications. The poor communication between the Halal Executives and the Halal Auditors can be attributed to the shortage of staff in JAKIM/JAIN (Noordin et al., 2014).

Although there is quite extensive literature available on halal issues, there is still a lack of research regarding the challenges faced by the Halal Auditors and the members of the HCP. Various studies have been conducted to understand the viewpoints of stakeholders especially from the industries, but so far no research has triangulated the viewpoints of the different parties regarding the Halal Auditor's role and challenges, including the opinion of the HCP. Factors relating to Halal Auditors should be studied in order to come up with innovation to enable effective performance and management of their work (Reed et al., 2014). Therefore, the aim of this study is to gain the viewpoints of all the parties involved in the halal certification process. It seeks to carry out a detailed investigation based on the data gathered from three viewpoints, namely the perspectives of the Halal Auditors, the Halal Executives, and the HCP.

\section{Materials and methods}

Exploratory research was done using qualitative research methodology. The main method of data collection to achieve the objective of this study is the conduct of in-depth interviews. All the interviews were audio and video recorded, then transcribed verbatim by the researchers before being manually analyzed. Purposive sampling was utilized to choose samples with specific expertise and knowledge, as required by the researchers. Although this method can contribute useful and accurate data to answer the research question, its limitation is that the findings cannot be generalized to the population. A total of 15 respondents participated in these interviews. The respondents are the heads of Halal Auditor from Hub Halal Division, JAKIM and the Halal Management Division, JAIS, the Halal Panel from JAIS, 13 Halal Executives from selected companies with experience in applying for Malaysian halal certificate, and a personnel from the Ministry of Energy, Science, Technology, Environment and Climate Change (MESTECC).

The instrument of this study is the semi-structured interview questions. The interview guide was developed based on literature review and upon consulting the experts in halal management field. It consists of two parts: demographic questions, and semi-structured interview questions related to the research. The interview sessions were conducted at a quiet workplace area to ensure privacy, and each session took between eight minutes to one hour. The purpose of the interview had been briefed to each respondent before the interview session began and the researchers issued informed consent letters to each respondent. The interviews were conducted in Malay and English and were video and audio recorded. Probe techniques were used based on the answers given by the respondents. The interview sessions kicked off on 9th December 2017 and concluded on 28th December 2017.

Data obtained from the interviews were transcribed from either the audio or video recording. In qualitative data analysis, the first step is preparing and managing the data, reducing and condensing codes into themes. Themes were identified by looking at the information pattern. The process of data collection and analysis took place simultaneously. When the first data of the interview was done, some new codes might emerge from the data. The saturation of data is reached by using the constant comparative method. Selective coding was applied to make sure that there will be a good storyline. Later, the information was triangulated and the findings deduced from the analysis.

\section{Results and discussion}

This section discusses the results of the triangulation analysis obtained from the interviews conducted on all three categories of stakeholders. First, the challenges in undergoing the halal certification process are discussed. Then, the suggested initiatives to improve the performance of Halal Auditors are highlighted. This study reveals a few hidden factors that cause the delay in the halal certification applications. Among them are lack of manpower, the Halal Auditors' inadequate skills and knowledge, problems with MYeHALAL system, challenges in reviewing the halal certification application, lack of proper guidelines for the Malaysia Halal Certification, and competition from foreign certification bodies.

\subsection{Lack of manpower}

Lack of manpower is the main factor that causes the 
delay in giving halal certification, especially when so many halal certification applications are received at any one time. All the respondents, regardless of whether they are from JAKIM, JAIS, or the industries, acknowledged this fact. Lack of manpower and too much workload can cause stress and this will affect the performance of the Halal Auditors. This finding is in line with the findings gathered from past studies. The time taken to complete the audit tasks depends on the number of auditors available and if there is inadequate number of staffs to bear the burden, the auditors will suffer from emotional exhaustion, fatigue, and depression (Agoglia et al., 2010; Yan and Xie, 2016). Among the comments from the auditors was:

"We received $1400++$ halal certification applications in 2016 but in September 2017 we received almost 2000 halal applications including renewal applications. This creates more workload since previously we only handle the new applications. Our workload has doubled and therefore new improvements in terms of SOP are needed to overcome the issue of lack of manpower."

To overcome this problem, JAKIM and JAIS have, on many occasions, hired contract employees to share the workload and lighten the burden. Unfortunately, this leads to the issue of poor competency among the Halal Auditors. This finding is similar to that of previous studies such as Noordin et al. (2014), which found that lack of staff is the reason why the Halal Auditors take a long time to reply to inquiries received from the industries. In addition, Ahmad et al. (2017) also found that lack of manpower hinders the ability of Halal Executives to develop food management systems.

\subsection{Recruitment scheme of halal auditors}

Halal Auditors are hired by the Federal and State governments using different methods of recruitment. The shariah auditors from JAKIM possess pure shariah qualifications, while their technical Halal Auditors come from the Ministry of Health. JAIS, on the other hand, directly recruits their own technical or shariah officers. This creates a disparity in terms of the recruitment process of Halal Auditors by the Federal and State governments. The matter becomes more complicated with the introduction of new schemes such as halal certification for logistics and pharmaceutical industries. This problem is non-existent in the food industry since most of their auditors come from the food science background.

An initiative by JAKIM to send their Halal Fast Force (HFF) to speed up the reviewing process in the states is welcomed. However, this initiative can only be a short-term solution. One of the respondents had given a thorough explanation of how Halal Auditors are chosen:

"JAKIM officers are purely those with shariah background in the Department of Islamic Development Malaysia (JAKIM). So, for technical staff, we are borrowing Health and Food Quality Officers from the Ministry of Health (MOH). We do not hire chemists or pharmacists and we rely on these food tech persons. We at JAKIM are civil servants and therefore fall under the Public Service Commission (SPA) and the Malaysian Public Service Department (JPA) scheme."

\subsection{Competency among Halal Auditors}

The lack of competence among Halal Auditors can be seen from their inability to handle the challenges in the halal reviewing process. The identification of new raw materials is the main challenge which Halal Auditors have difficulty dealing with (Lockley and Bardsley, 2000). When Halal Executives make an inquiry about the use of new raw material, they expect the Halal Auditors to provide them with the answers. However, on many occasions, the industry representative ends up being the one to explain the status of the raw material, instead of the other way around. The concern is that industry representatives can manipulate their explanation and the auditors are unable to determine the truth. This lack of competency can ruin the credibility of the halal authority. One of the respondents had expressed her concern that the auditors are not sufficiently competent:

"The authorities need to know important information instead of asking the industry to provide them with the answers. When an auditor asks the industry, it can become bias and easily manipulated. The companies may cheat on them if Halal Auditors simply accept the industry's explanation. This is not good for JAKIM's reputation".

The above is consistent with the concerns raised by Noordin et al. (2014) on the Halal Auditors' inability to answer the inquiries put forward by the industries. Poor communication between the Halal Executives and the Halal Auditors indicates the latter's lack of competence. In comparison between Halal Auditors in Malaysia and the auditors of Majelis Ulama Indonesia (MUI), it is found that MUI has experts in the cosmetic scheme who are permanent and fully trained, while in Malaysia only JAKIM has that kind of expertise. For example, when doing an on-site audit, Halal Auditors will just review the Halal Assurance System file without making any comments, compared to Halal Auditors from MUI who will guide the Halal Executives throughout the process. This shortcoming, namely the Halal Auditors' lack of technical knowledge, has even been admitted by JAKIM/ 
JAIS.

\subsection{The need for clear guidelines}

JAKIM/JAIS must improve the competency of their Halal Auditors by providing clear guidelines or checklist to guide them in reviewing the application documents. The Halal Executives argued that JAKIM only provides a brief explanation of the implementation of the Halal Assurance System, compared to the comprehensive guidelines provided by MUI. The lack of guidance is demonstrated with the absence of a proper checklist to check the raw materials' critical background. This problem does not only affect Halal Executives but also the Halal Auditors since there are no clear rules regarding permitted raw materials in the critical ingredient list. This will leave both Halal Auditors and Halal Executives in the dark as to what ingredients are permitted. If JAKIM can provide the permitted list of ingredients, this will greatly help the Halal Auditors since clear guidelines and direction from the management can improve the subordinate's competency.

This problem was raised by most respondents representing Halal Executives. Among the complaints were:

"Since I have to develop this halal assurance system, reference is made to the MUI guidelines but not JAKIM since the MUI guidelines are more comprehensive and detailed. Honestly, they are a step ahead of JAKIM."

JAKIM also has difficulty synchronizing the understanding between them as the halal authority and the industries. One of its weaknesses is the chosen method of communicating information, which is through industry associations. Not all companies join their industry associations and therefore those who are not members of their industry association may not obtain the updated information.

\subsection{MYeHALAL System}

All the stakeholders interviewed mentioned the use of MYeHALAL system and associated it with the Halal Auditors' poor level of competency. The Halal Executives voiced out their dissatisfaction with the MYeHALAL system as they have faced technical problems with the system such as the problematic saving capability and the name of person-in-charge being absent. Compared to MUI's CEROL system which is much more user-friendly, the MYeHALAL system is outdated and not very stable. In addition, the applicants still need to submit the application manually which would be a hassle for the Halal Executives. The problems become severe when the industry tends to combine two renewal halal certification applications whilst the system does not encourage this practice. According to Noordin et al. (2014), an updated IT system will be very beneficial to ensure the efficiency of the halal certification application process. It was hoped that the MYeHALAL system will bring improvements to the halal certification process but unfortunately this has not happened.

\subsection{Competition with foreign halal certification bodies}

A study by Schipper and Vincent (2003) examined the risks and responsibilities borne by auditors when clients expect them to complete the audit work within a given time. Evolving knowledge in economics, finance, technology, and industry patterns creates a barrier for auditors to perform their work, especially if they themselves are struggling due to lack of skills and knowledge. Halal Auditors become stressed and the gap between their competency and clients' expectations become even wider. JAKIM's position as a pioneer Halal Certification Application body has been affected by the availability of another foreign certification body, namely the MUI. Many companies from Malaysia tend to apply for the halal logo from the MUI because the MUI provides proper guidelines and their halal logo can be used in Malaysia. Their documentation checklist is comprehensive and their Halal Auditors are competent and able to answer questions coming from each scheme. Hence, they perform their roles better as they not only issue halal certification but they also educate the industries, compared to JAKIM which only endorses the non-conformance reports. Among the comments made by the respondents is as follows:

"Halal Assurance System was first introduced by MUI, so if you want to attend any seminar for Halal Assurance System (HAS), it will be organized by MUI. Nowadays, there are many overseas certification bodies which are competing with us. Thailand, for example, is fast-moving and we have to do something new to preserve our position as a pioneer."

Both Soesilowati (2011) and Wahid (2012) concluded that the lack of integration and weak monitoring in the agency itself has led to problems in the certification process. Effective steps need to be taken to overcome these weaknesses.

\subsection{Initiatives for improvement}

The respondents also offered suggestions on how to overcome the challenges. The setting-up of the Malaysian Halal Council that involves all industry players and halal certification bodies is welcomed. This council can organize an ijtimak or conference and a round table discussion can be held from time to time. The establishment of the Halal Professional Board can 
also strengthen the industry by not only focusing on training for Halal Executives but also Halal Auditors. A series of training needs to be conducted, especially to increase Halal Auditors' knowledge with regards to the new scheme of cosmetics and pharmaceutical products. It was also suggested for JAKIM to collaborate with other agencies to hold seminars and job training in order to enhance the skills of Halal Auditors and improve their level of professionalism. This suggestion is in line with existing theory and literature, whereby Chan (2008) and Karaman et al. (2012) had emphasized the important roles played by employers in developing the competencies of their employees. This initiative has been highlighted by one of the respondents.

"In terms of qualification, JAKIM has special programs or courses to enable the auditors to be truly competent and efficient in carrying out halal certification. Besides, the senior auditors will guide the junior auditors. For example, if there is a new employee coming in, I will be a mentor. I will encourage and guide him from time to time to make sure that he reaches the standards required by the department. In terms of becoming a halal auditor, qualification is secondary but what matters most is attitudes and discipline. The auditors should also be really honest in carrying out their tasks. We have to make sure that the auditors possess strong integrity to guarantee strict sharia compliance."

One of the respondents representing the auditors shared his experience in increasing auditors' competency.

"One of the efforts made was calling in other bodies that have extensive experience in auditing. For example, SIRIM (Scientific and Industrial Research Institute of Malaysia) was called upon to guide and teach the auditors. Apart from that, there are also courses held to develop the auditors' self-confidence. JAKIM also collaborates with other agencies such as the Malaysian Islamic Training Institute (ILIM) which has a cluster called the halal management and the Islamic economy. In the halal hub, JAKIM has a unit placed under the Malaysian Halal Council and this unit is called the Halal Industry Research Academy (HIRA)."

Apart from the steps stated above, the MYeHALAL system also needs an overhaul before it can be fully utilized. The system needs to be upgraded so that hard copy submission can be eliminated from the application process. The system also needs to be incorporated into HAS as this can indirectly speed up the process of certification. In addition, JAKIM can take other initiatives to speed up the halal certification process such as implementing Inisiatif Segera Pensijilan Halal
Malaysia (ISPHM). The purpose of this initiative is to speed up the process of issuing a new halal certification and renewing existing ones. In order to achieve this, the halal certification body needs to increase its manpower who are competent to handle all situations in halal certification. Halal Auditors who have shariah background must compliment those who have a science background. Therefore, higher institutions should prepare their students with noble values and expose them to the real working environment in the halal industry. There is also the possibility of Halal auditors being recognized as professionals. The efforts towards this must be put in by all parties concerned including higher learning institutions, the Ministry of Energy, Science, Technology, Environment and Climate Change (MESTECC), and JAKIM. If this can be achieved, then Halal Auditors will be recognized as being competent in carrying out the certification task and thus the credibility of the halal certification agency will be safeguarded. Figure 1 illustrates the themes which have emerged following the in-depth interviews held with all the respondents.

\section{Conclusion}

This study highlights the challenges faced by the halal certification authorities in the halal certification process in Malaysia, as well as the initiatives that can be taken to improve their performance. This study finds that there are many challenges that need to be overcome by the Malaysian Halal certification bodies at both Federal and State level, for example, the shortage of manpower that has lead Halal Auditors to be overburdened with heavy workload. The difference in administration between JAKIM and JAIS (which represent Federal and State level government respectively) need to be resolved. The service department of these agencies should provide more posts for Halal Auditors. The posts should provide opportunities in various fields related to halal certification such as management, food and non-food science qualifications and also information technology to help overhaul and upgrade the MYeHALAL system. At the same time, more halal certification process centers in the various districts in Malaysia are set up, to ensure that the time to process halal certification can be shortened and to provide job opportunities for fresh graduates. Halal certification authorities in Malaysia need to provide a more thorough and industry-friendly halal system guidance which can facilitate the development of their halal guarantee system based on factors such as company size, number of employees, product type, and production involving export and import. The Halal Professional Board course can be embedded in a Bachelor's degree course, especially relating to halal or related products in food production, food services, 

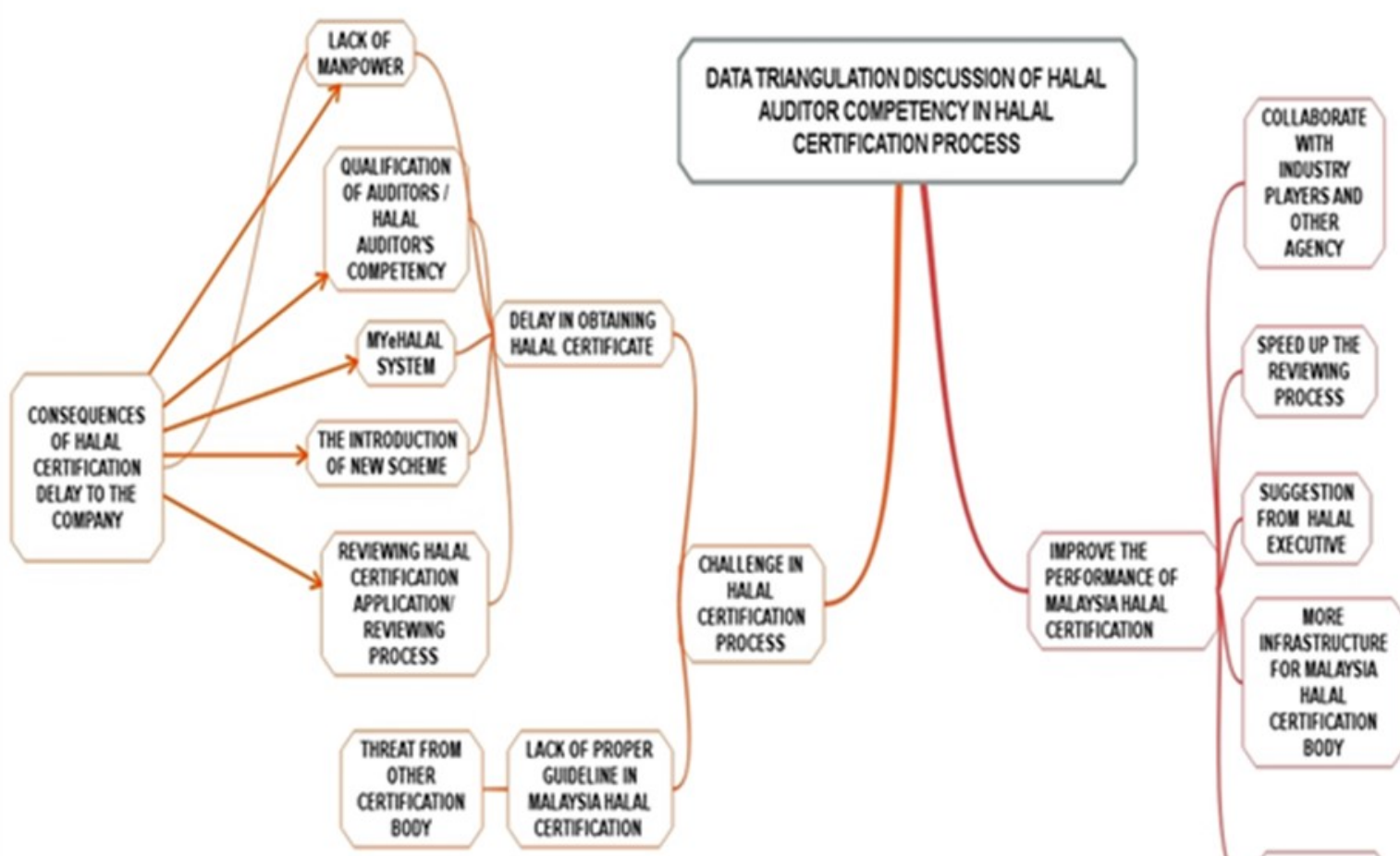

Figure 1. Data triangulation map

logistics, and others. University students should be exposed to the course so that they have some basic knowledge of halal management, given the fact that halal management is needed across the disciplines in shariah, management, marketing, law, business, science, and technology. More studies need to be conducted to strengthen the image of the halal certification authority as a trusted and credible certification body in Malaysia.

\section{Conflict of Interest}

The authors declare no conflict of interest.

\section{Acknowledgments}

This research was supported by Ministry of Higher Education, Fundamental Research Grant Scheme (FRGS) "Developing alternative measures in protecting consumers relating to Halal Food industries" FRGS/1/2016/SS06/UPM/02/9.

\section{References}

Agoglia, C.P., Brazel, J.F., Hatfield, R.C. and Jackson, S.B. (2010). How do audit workpaper reviewers cope with the conflicting pressures of detecting misstatements and balancing client workloads? $A$ Journal of Practice and Theory, 29(2), 27-43. https://doi.org/10.2308/aud.2010.29.2.27

Ahmad, A.N., Rahman, R.A., Othman, M. and Abidin,
U.F.U.Z. (2017). Critical success factors affecting the implementation of halal food management systems: perspective of halal executives, consultants and auditors. Food Control, 74, 70-78. https:// doi.org/10.1016/j.foodcont.2016.11.031

Arif, S., Sidek, S. and Bakar, N.A. (2017). Using Actornetwork Theory to analyze the usage of Myehalal system: a conceptual framework. In Li, Y., Hunjet, A. and Roncevic, A. (Eds.). Economic and Social Development (Book of Proceedings). 20th International Scientific Conference on Economic and Social, 27-28 April 2018, p. 184-193. Croatia, Poland: Varazdin Development and Entrepreneurship Agency, City of Prague, University North, Croatia, Faculty of Management University of Warsaw, Poland.

Buang, A.H. and Mahmod, Z. (2012). Isu dan cabaran badan pensijilan halal di Malaysia. Jurnal Syariah, 20(3). Retrieved from January 3, 2018 from http:// ejum.fsktm.um.edu.my/article/1363.pdf.

Chan, E.S. (2008). Barriers to EMS in the hotel industry. International Journal of Hospitality Management, 27 (2), $\quad$ 187-196. https://doi.org/10.1016/ j.ijhm.2007.07.011

Elistina, A.B., Nashaqilla, N.R., Afida Mastura, M.A. and Mohidin, O. (2017). Consumers' trust and values towards halal cosmetics and personal care products. Malaysian Journal of Consumer and 
Family Economics, 20(S2), 21-34.

Hashim, H.I.C. and Shariff, S.M.M. (2016). Halal supply chain management training: issues and challenges. Procedia Economics and Finance, 37, 33-38. https:// doi.org/10.1016/S2212-5671(16)30089-2

Ibrahim, I.S., Husny, Z.J.M., Rozan, M.Z.A. and Tan, M.I.I. (2013). Assessment on the utilization of current halal certification technologies by halal industry players in Malaysia presented at the Proceedings of the World congress on Engineering and Computer Science 2014, 22-24 October 2014. San Francisco, USA. Retrieved from https:// pdfs.semanticscholar.org/56ae/98e3236db43b241cef 633368fded7abcc55e.pdf.

Jabatan Kemajuan Islam Malaysia (JAKIM). (2015). Manual Procedure for Malaysia Halal Certification (Third Revision) (2014). Retrieved from www.halal.gov.my/v4/images/pdf/ MPPHM2014BI.pdf

Karaman, A.D., Cobanoglu, F., Tunalioglu, R. and Ova, G. (2012). Barriers and benefits of the implementation of food safety management systems among the Turkish dairy industry: a case study. Food Control, 25(2), 732-739. https://doi.org/10.1016/ j.foodcont.2011.11.041

Khairi, M.O., Nik Kamariah, N.M., Gaboul Ahmed, I. and Fatihya, M.A.A. (2012). The direct effects of halal product actual purchase antecedents among the international Muslim consumers. American Journal of Economics, Special Issue, 87-92. https:// doi.org/10.5923/j.economics.20120001.20

Lockley, A.K. and Bardsley, R.G. (2000). DNA-based methods for food authentication. Trends in Food Science and Technology, 11(2), 67-77. https:// doi.org/10.1016/S0924-2244(00)00049-2

Marzuki, S.Z.S., Hall, C. and Ballantine, P. (2012). Restaurant managers' perspectives on halal certification. Journal of Islamic Marketing, 3, 47-58. https://doi.org/10.1108/17590831211206581

Noordin, N., Noor, N.L.M. and Samicho, Z. (2014). Strategic approach to halal certification system: an ecosystem perspective. Procedia-Social and Behavioral Sciences, 121, 79-95. https:// doi.org/10.1016/j.sbspro.2014.01.1110

Osman, S., Ahmad, M.H. and Jalil, A. (2019). The use of Islamic element in business: syariah analysis. Al'Abqari: Journal of Islamic Social Sciences and Humanities, 17, 39-51

Prabowo, S., Abd Rahman, A., Ab Rahman, S. and Samah, A.A. (2015). Revealing factors hindering halal certification in East Kalimantan Indonesia. Journal of Islamic Marketing, 6(2), 268-291. https:// doi.org/10.1108/JIMA-05-2014-0040
Reed, K., Goolsby, J.R. and Johnston, M. K. (2016). Listening in and out: listening to customers and employees to strengthen an integrated marketoriented system. Journal of Business Research, 69 (9), 3591-3599. https://doi.org/10.1016/ j.jbusres.2016.01.002

Schipper, K. and Vincent, L. (2003). Earnings quality. Accounting Horizons, 17, 97-110. https:// doi.org/10.2308/acch.2003.17.s-1.97

Shahwahid, F.M., Othman, N. and Saidpudin, W. (2017). Challenges and ways improving Malaysia halal food industry. Science International, 29(2), 149-149.

Soesilowati, E.S. (2011). Business opportunities for halal products in the global market: Muslim consumer behaviour and halal food consumption. Journal of Indonesian Social Sciences and Humanities, 3, 151160. https://doi.org/10.14203/jissh.v3i1.50

Soraji, A, Awang, M. and Mohd Yusoff, A. (2017). Malaysia halal trust: between reality and challenges. International E-Journal of Advance in Social Sciences, 3(7), 197-204. https://doi.org/10.18769/ ijasos.309676

Trade Description Act 2011. Act 730. (MY).

Trade Descriptions (Certification and Marking of Halal) Order 2011. Act 730. (MY). Retrieved from http:// www.federalgazette.agc.gov.my.

Trade Descriptions (Define of Halal) Order 2011. Act 730. (MY). Retrieved from http:// www.federalgazette.agc.gov.my.

Wahab, N.A., Shahwahid, F.M., Hamid, N.A.A., Othman, N., Ager, S.N.S., Abdullah, M. and Saidpudin, W. (2016). Contributions of Malaysia and Singapore in the development of halal industry in the Asean region. Asian Journal of Social Sciences and Humanities, 5(2)37-46.

Wahid, N. (2012). Melihat produk halal dari perspektif keunggulan komparatif. Jurnal Halal, 98, 30-31.

Wan Hassan, W.M. and Awang, K.W. (2009). Halal food in New Zealand restaurants: an exploratory study. International Journal of Economics and Management, 3(2), 385-402

Wilson, J.A. and Liu, J. (2010). Shaping the halal into a brand? Journal of Islamic Marketing, 1(2), 107-123. https://doi.org/10.1108/17590831011055851

Yan, H. and Xie, S. (2016). How does auditors' work stress affect audit quality? Empirical evidence from the Chinese stock market. China Journal of Accounting Research, 9(4), 305-319. https:// doi.org/10.1016/j.cjar.2016.09.001

Zakaria, Z. and Ismail, S.Z. (2014). The Trade Description Act 2011: regulating 'halal' in Malaysia. Retrieved on February 15, 2017 from http:// eprints.um.edu.my/13062/1/ED0614020.pdf 